\title{
HEAT RECOVERY FROM THE EXHAUST FLUE GASES OF NON-OX FURNACE
}

\author{
Aditya Karadbhajne \\ Department of ME \\ Yeshwantrao Chavan College of \\ Engineering, Nagpur, Maharashtra, India. \\ Shubham Gondane \\ Department of ME \\ Anjuman College of Engineering and \\ Technology, Nagpur, Maharashtra, India.
}

\author{
Shubham Belsare \\ Department of ME \\ Dr. Babasaheb Ambedkar College of \\ Engineering and Research, Nagpur, \\ Maharashtra, India. \\ Himanshu Ninawe \\ Department of ME \\ Priyadarshani Institute of Engineering and \\ Technology, Nagpur, Maharashtra, India.
}

\author{
Pankaj Bendre \\ Department of ME \\ Government College of Engineering, \\ Nagpur Maharashtra, India.
}

\begin{abstract}
This is the industrial project based on the recovery of heat from exhaust flue gases. Exhaust flue gases from non-ox furnace at Continuous Galvalume line in JSW Steel Coated Products Ltd as observed leaves the furnace at $200^{\circ} \mathrm{C}$ and is effluated to atmosphere through chimney.
\end{abstract}

The advantage of recovering heat from flue gases of a propane fired non-ox furnace aiming to trap heat from enthalpy of flue gases released to the chimney at 200 degrees centigrade and proposes to accommodate the trapped heat to heat the air used in hot air dryer from ambient to 80 degrees centigrade, existing heat exchanger uses steam to elevate the temperature of air by regulating the mass flow rate of the flue gases. In this improvement technique the task is to heat ambient air using heat of flue gases averagely leaving the furnace at $\mathbf{2 0 0}$ degrees centigrade. The exhaust blower blows flue gases to heat exchanger at $55000 \mathrm{~m} 3 / \mathrm{hr}$ replacing steam in the existing heat exchanger using flue gases to use its enthalpy to better use. Existing system uses steam to increase the temperature of air, by cutting the supply of steam with exhaust flue gases we are able to use non-ox furnace to its fullest capacity. The proposed improvement eliminates the plants dependence on Coal and indirectly diminishes daily water consumption.
Key words: Galvalume, Heat Recovery, Heat Exchanger, Hot Air Drye

\section{INTRODUCTION}

Galvalume process is carried out to protect the steel and iron product from the atmospheric conditions. During this process hot air is required which is prepared by making use of steam. We intend to use heat available from chimney to preheat the air used in the Hot Air dryer in the GAL plant.

\subsection{Problem Statement}

As observed the exhaust flue gas from Non-Ox furnace has the significant enthalpy that released to atmosphere through chimney. It was identified that a source of heat is being wasted.

\subsection{Problem Objective}

Following are the objectives of the project:

- Existing system uses steam to increase the temperature of air, by cutting the supply of steam with exhaust flue gases we are able to use non-ox furnace to its fullest capacity.

- The proposed improvement eliminates the plants dependence on Coal and indirectly diminishes daily water consumption.

- Reduced cost of acquiring Coal. 


\section{International Journal of Engineering Applied Sciences and Technology, 2019 \\ Vol. 4, Issue 7, ISSN No. 2455-2143, Pages 233-235 \\ Published Online November 2019 in IJEAST (http://www.ijeast.com)}

\subsection{Research Objective}

This thesis proposes whole idea regarding the project HEAT RECOVERY FROM EXHAUST FLUE GASES OF NON-OX FURNACE. Our aim is to put necessary details about the project in front of the readers. It gives the information about necessary component, their contribution in the project etc. Also the thesis provides work we have done for making this project a unique one.

\section{WORKDONE}

\subsection{Overview}

Aim of the project is to replace maximum amount of steam going to heat Exchanger of Hot Air Dryer for heating of atmospheric air by the Exhaust flue gases coming from the furnace. In designing and validation of this change we have gone through a process which will be explained in this chapter. This chapter comprises of the discussions about the designing, calculation and discussion of various facts and figure. It will also include the drafting of CAD models and the mathematical calculations done in designing the system for recovery of heat from exhaust gas. Designing process and methods used will also be discussed along with the specifications of components used.

\subsection{Plan of Work}

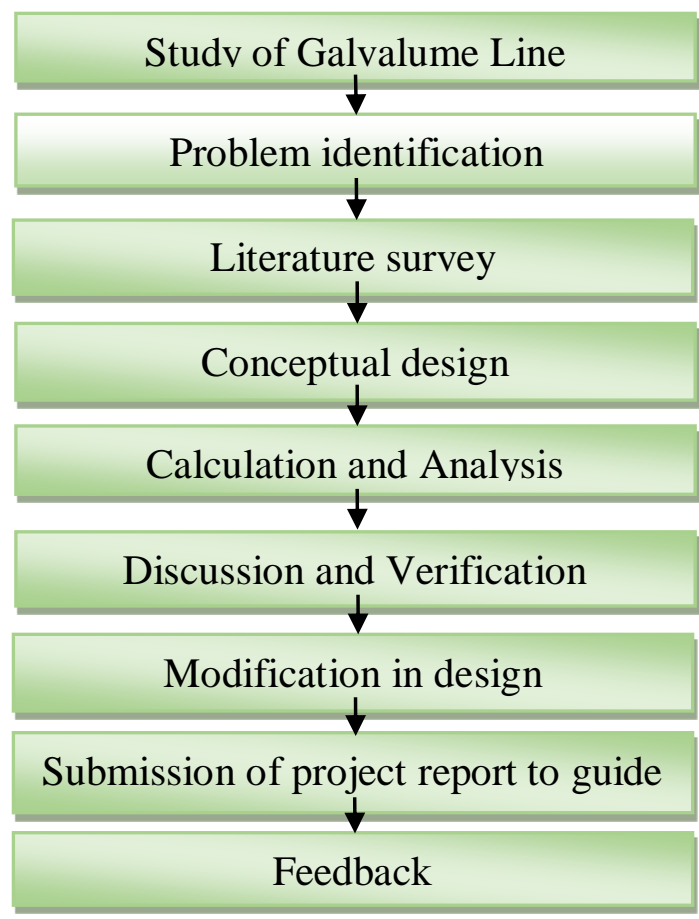

\section{DESIGN CALCULATION}

\section{Phase 1}

Project has two main task in which $1^{\text {st }}$ task is to supply exhaust gas from Exhaust blower of non-ox furnace to the heat exchanger of hot air dryer while $2^{\text {nd }}$ task is to check for the suitability of exhaust gas in heat exchanger by checking its effectiveness. Total distance between the Exhaust blower and Heat exchanger is about $30 \mathrm{~m}$. So it was a big task to design a system for minimum heat loss so that more amount of temperature can be available at the inlet of heat exchanger.

\section{Design Parameter}

\section{- Exhaust Blower}

Capacity: $55000 \mathrm{~m}^{3} / \mathrm{hr}$

Power: $52.11 \mathrm{kw}$

Pressure: 1.01325bar

Fan speed: $1104 \mathrm{rpm}$

Fan efficiency: $84.5 \%$

Duct size: $762 \mathrm{~mm} * 609 \mathrm{~mm}$

\section{- Exhaust Gas}

Content: $\mathrm{CO}_{2}$ (maximum percentage), Air, $\mathrm{N}_{2}, \mathrm{CO}$

Temperature: $\operatorname{Max} 300^{\circ} \mathrm{C}$ to $\operatorname{Min} 150^{\circ} \mathrm{C}$

Calculation Temperature: $250^{\circ} \mathrm{C}$

Density of $\mathrm{CO}_{2}: 1.05 \mathrm{~kg} / \mathrm{m}^{3}$

Mass flow rate: $16 \mathrm{~kg} / \mathrm{s}$

\section{Calculations for Pipe}

Considerations: 1) Taking 15inch of pipe for supplying exhaust gas

2) Material of pipe taken as Mild Steel

3) Conductivity of MS found as $53 \mathrm{w} / \mathrm{mk}$

4) Convective heat transfer taken as $8 w / \mathrm{m}^{2} \mathrm{k}$

5) Available temperature $250^{\circ} \mathrm{C}$

$\therefore$ Total Heat loss in pipe without Insulation is as follow,

$\mathrm{Q}_{\text {loss }}=$ Heat loss by radiation + Heat loss by convection

$$
\begin{aligned}
& =\left\{\sigma^{*} \varepsilon^{*} \mathrm{~A}^{*}\left(\mathrm{~T}_{\max }{ }^{4}-\mathrm{T}_{\mathrm{s}}^{4}\right)\right\}+\left\{\mathrm{h} * \mathrm{~A} *\left(\mathrm{t}_{\max }-\mathrm{t}_{\mathrm{s}}\right)\right\}
\end{aligned}
$$

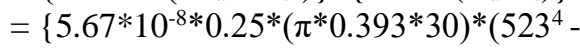

$$
\begin{aligned}
& \left.\left.303^{4}\right)\right\}+\{8 *(\pi * 0.393 * 30 *(250-36)\} \\
& =99000 \mathrm{~W}
\end{aligned}
$$

\section{- With insulation Heat loss}

We have made iteration for deciding thickness of insulation over pipe associated heat loss

Assumptions:

1) Taking glass wool as Insulating material

2) Conductivity $0.0372 \mathrm{w} / \mathrm{mk}$ 


\section{International Journal of Engineering Applied Sciences and Technology, 2019 \\ Vol. 4, Issue 7, ISSN No. 2455-2143, Pages 233-235 \\ Published Online November 2019 in IJEAST (http://www.ijeast.com)}

Table 1 Iteration for the thickness of insulation

\begin{tabular}{|c|c|}
\hline Heat loss $(\mathrm{Kw})$ & $\begin{array}{c}\text { Thickness of } \\
\text { insulation }(\mathrm{mm})\end{array}$ \\
\hline 50 & 2.4 \\
\hline 20 & 4 \\
\hline 5 & 4.27 \\
\hline 2 & 7 \\
\hline 1 & 12 \\
\hline 0.5 & 22.5 \\
\hline
\end{tabular}

- Temperature available at inlet of heat exchanger

Heat available at exhaust blower

$\mathrm{Q}=\mathrm{Mh} * \mathrm{Cph} *(\mathrm{Th} 1-\mathrm{Th} 2)$

$=16 * 995 *(250-100)$

$=2289000 \mathrm{~W}$

Taking $7 \mathrm{~mm}$ of insulation by glass wool on the pipe

Hence total heat loss for $30 \mathrm{~m}$ pipe comes to $60 \mathrm{KW}$

After subtracting this heat loss from available heat total $2229000 \mathrm{~W}$ of heat remains

$\therefore 2229000=16 * 995 *($ Th $1-100)$

$\mathrm{Th} 1=240^{\circ} \mathrm{C}$

Hence after applying insulation of glass wool we getting $240^{\circ} \mathrm{C}$ of temperature at the inlet of heat exchanger.

If insulation thickness raise it can also lead to decrease in heat loss at certain value.

$\therefore$ Hence finalizing the parameters of delivery pipe

Inlet diameter: $381 \mathrm{~mm}$

Outlet diameter: $393 \mathrm{~mm}$

Insulation thickness: $7 \mathrm{~mm}$ (can be alter if required)

Material of pipe: Mild Steel

Thermal Conductivity of pipe: $51 \mathrm{w} / \mathrm{mk}$

- Costing of insulation

$\therefore \mathrm{V}_{1}-\mathrm{V}_{2}=\left(\pi^{*} \mathrm{r}_{\mathrm{o}}{ }^{2 *} \mathrm{~h}\right)-\left(\pi^{*} \mathrm{r}_{\mathrm{i}}{ }^{2 *} \mathrm{~h}\right)$

$$
=\left(\pi^{*} 0.203^{2 * 30}\right)-\left(\pi * 0.1965^{2 * 30}\right)
$$$$
=0.24473 \mathrm{~m}^{3}
$$

Density of MS: $16 \mathrm{Kg} / \mathrm{m}^{3}$

$\therefore$ Total weight of pipe $=0.24473 * 16$

$=3.91 \mathrm{~kg}$

$\therefore$ Total price $=3.91 * 33=\mathrm{Rs} 129$

\section{- Cost of Pipe}

$$
\begin{aligned}
& \begin{aligned}
\begin{aligned}
\mathrm{V}_{1}-\mathrm{V}_{2}= & \left(\pi * \mathrm{r}_{\mathrm{o}}{ }^{2 *} \mathrm{~h}\right)-\left(\pi^{*} \mathrm{r}_{\mathrm{i}}{ }^{2 *} \mathrm{~h}\right) \\
& =\left(\pi^{*} 0.1965^{2 * 30}\right)-\left(\pi^{*} 0.1905^{2 * 30)}\right. \\
& =0.218843 \mathrm{~m}^{3}
\end{aligned} \\
\text { Density of MS: } 8055 \mathrm{Kg} / \mathrm{m}^{3}
\end{aligned} \\
& \begin{array}{l}
\therefore \text { Total weight of pipe }=8055^{*} 0.21884 \\
=1762 \mathrm{~kg}
\end{array} \\
& \begin{array}{l}
\therefore \text { Total price }=1762 * 83=\mathrm{Rs} 146308
\end{array}
\end{aligned}
$$

From above costing it is found that as per the thickness of material and price available for the material in the current market it get vary.

\section{Phase 2}

In this phase work is done to check for the effectiveness of heat ex-changer by using NTU method and the same value is compared with another formula to calculate the outlet temperature of exhaust gas from heat exchanger. For obtaining the values various assumption have made.

\section{Design Parameter}

\section{- Hot air dryer Blower}

Capacity: $42000 \mathrm{~m}^{3} / \mathrm{hr}$

Power: $36 \mathrm{kw}$

Pressure: 1.01325bar

Fan speed: 1500rpm

Fan efficiency: $84.5 \%$

Duct size: $609 \mathrm{~mm} * 457 \mathrm{~mm}$

Mass flow rate of air: $13.42 \mathrm{~kg} / \mathrm{s}$

\section{- Heat Exchanger}

Type: Cross flow single pass vertical type finned heat exchanger

Tube ID: $25.4 \mathrm{~mm}$

Tube OD: $30.7 \mathrm{~mm}$

Thickness: $2.65 \mathrm{~mm}$

Tube Material: SA-179 Gr Seamless

Length: $1170 \mathrm{~mm}$

Number of tubes: 20

Length: $1 \mathrm{~m}$

Distance between two tubes: $55 \mathrm{~mm}$

Thermal conductivity of tube: $51.9 \mathrm{w} / \mathrm{m}^{2} \mathrm{k}$

\section{Calculation for Heat Ex-changer}

- Heat required to raise temperature of atmospheric air from $30^{\circ} \mathrm{C}$ to $80^{\circ} \mathrm{C}$

$$
\therefore \mathrm{Q}=\dot{\mathrm{m}}^{*} \mathrm{C}_{\mathrm{p}} * \Delta \mathrm{T}
$$

Let, air is present at $30^{\circ} \mathrm{C}$ and $\mathrm{C}_{\mathrm{P}}$ of air is 1005 $\mathrm{J} / \mathrm{kg} \cdot \mathrm{k}$

$\mathrm{Q}=13.42 * 1005 *(80-30)$

$\therefore \mathrm{Q}=674.355 \mathrm{KW}$

Total $674.355 \mathrm{kw}$ heat will be required to raise the temperature of air from $30^{\circ} \mathrm{C}$ to $80^{\circ} \mathrm{C}$

\section{- Calculating overall heat transfer coefficient (U)}

Calculating for Overall heat transfer coefficient (U) for Heat Exchanger When saturated Steam is used as a hot fluid 
Steam at a pressure of $2.5 \mathrm{~kg} / \mathrm{cm}^{2}$ and $126^{\circ} \mathrm{C}$ temperature enters into heat exchanger and leave at $118^{\circ} \mathrm{C}$

By using formula,

$\therefore \mathrm{Q}=\mathrm{U}^{*} \mathrm{~A}_{\mathrm{s}}{ }^{*} \mathrm{LMTD}$

Where,

LMTD: $61.66^{\circ} \mathrm{C}$

$A_{S}: 1.5959 \mathrm{~m}^{3}$
$Q: 674.355 \mathrm{kw}$

$\therefore 674355=\mathrm{U}^{*} 1.5959 * 61.66$

$\therefore \mathrm{U}=6859.40 \mathrm{w} / \mathrm{m}^{2} \mathrm{k}$

From here it is clear that Overall heat transfer for this heat exchanger is $6859.40 \mathrm{w} / \mathrm{m}^{2} \mathrm{k}$.

- Checking Heat Exchanger Effectiveness by Number of Transfer unit (NTU) Method using Exhaust Gas as a Hot fluid

$$
\therefore \mathrm{NTU}=\mathrm{U} * \frac{\mathrm{As}}{\mathrm{Cmin}}
$$

Here, $C_{\min }$ is a minimum fluid capacity rate amongst the Hot fluid and cold fluid

$\dot{\mathrm{m}}_{\mathrm{h}} * \mathrm{C}_{\mathrm{ph}}=16 * 1005=16080 \mathrm{w} / \mathrm{k}$

$\dot{\mathrm{m}}_{\mathrm{c}} * \mathrm{C}_{\mathrm{pc}}=13.42 * 1005=13487.1 \mathrm{w} / \mathrm{k}$

From above it is clear that fluid capacity rate for cold fluid is less than the hot fluid

$$
\begin{aligned}
& \dot{\mathrm{m}}_{\mathrm{c}} * \mathrm{C}_{\mathrm{pc}}<\dot{\mathrm{m}}_{\mathrm{h}} * \mathrm{C}_{\mathrm{ph}} \\
& \therefore \mathrm{C}_{\mathrm{min}}=13487.1 \mathrm{w} / \mathrm{k} \\
& \therefore \mathrm{NTU}=6859 * \frac{1.5959}{13487.1}
\end{aligned}
$$

$\therefore \mathrm{NTU}=0.81161$

As cross flow heat exchanger is used, $\varepsilon=1-\mathrm{e}^{-\mathrm{NTU}(1-\mathrm{C})} / 1-\mathrm{C}^{*} \mathrm{e}^{-\mathrm{NTU}(1-\mathrm{C})}$

where, $\mathrm{C}=\frac{\mathrm{Cmin}}{\mathrm{Cmax}}$

$\therefore \mathrm{C}=\frac{13487.1}{16080}$

$\therefore \mathrm{C}=0.8387$

$\varepsilon=1-\mathrm{e}^{-0.81161 *(1-0.8387)} / 1-0.8387 * \mathrm{e}^{-0.81161 *(1-0.8387)}$

$\varepsilon=0.4644$

Now, as we know that

$\varepsilon=\frac{\text { Actual heat transfer }}{\text { Maximum possible heat transfer }}$

$\therefore \mathrm{Q}_{\text {actual }}=\dot{\mathrm{m}}_{\mathrm{h}} * \mathrm{C}_{\mathrm{ph}} *\left(\mathrm{t}_{\mathrm{h} 1}-\mathrm{t}_{\mathrm{h} 2}\right)=\dot{\mathrm{m}}_{\mathrm{c}} * \mathrm{C}_{\mathrm{pc}} *\left(\mathrm{t}_{\mathrm{c} 2}-\mathrm{t}_{\mathrm{c} 1}\right)$

$\therefore \mathrm{Q}_{\text {actual }}=\dot{\mathrm{m}}_{\mathrm{c}} * \mathrm{C}_{\mathrm{pc}} *\left(\mathrm{t}_{\mathrm{c} 2}-\mathrm{t}_{\mathrm{c} 1}\right)$

$=13.42 * 1005 *(80-30)$ $=674355 \mathrm{~W}$

$\therefore \mathrm{Q}_{\max }=\mathrm{C}_{\min } *\left(\mathrm{t}_{\mathrm{h} 1}-\mathrm{t}_{\mathrm{c} 1}\right)$

$$
=13487.1 *(250-30)
$$
$=2967162 \mathrm{~W}$

$\therefore \varepsilon=\frac{\text { Qactual }}{\text { Qmax }}$

$\therefore 0.4644=\underline{\operatorname{mh} * \mathrm{Cph} *(\operatorname{th} 1-\mathrm{th} 2)}$

$\therefore 0.4644=\frac{16 * 995 *(250-\mathrm{th} 2)}{2967162}$

$\therefore \mathrm{t}_{\mathrm{h} 2}=163.44^{\circ} \mathrm{C}$.

$\therefore 0.4644=\frac{\mathrm{mc} * \mathrm{Cpc} *(\mathrm{tc} 2-\mathrm{tc} 1)}{296762}$

$\therefore 0.4644=\frac{29.42 * 1005 *(\mathrm{tc} 2-30)}{2967162}$

$\therefore \mathrm{t}_{\mathrm{c} 2}=132.16^{\circ} \mathrm{C}$

From above calculation it is cleared that outlet temperature of the exhaust gas is 163 .

\section{Observation table}

Table no.3.2: Variation in outlet temperature according to changing Inlet temperature of exhaust gas

\begin{tabular}{|c|c|c|c|c|c|c|c|}
\hline $\begin{array}{c}\text { Sr. } \\
\text { No. }\end{array}$ & $\begin{array}{c}\text { Mass } \\
\text { flow } \\
\text { rate } \\
\left(\dot{\mathrm{m}}_{\mathrm{h}}\right)\end{array}$ & $\begin{array}{c}\text { Inlet } \\
\text { temperature } \\
\left(\mathrm{t}_{\mathrm{h} 1}\right)\end{array}$ & $\begin{array}{c}\text { Effectiveness } \\
(\varepsilon)\end{array}$ & $\begin{array}{c}\text { Max heat } \\
\text { transfer } \\
(\mathrm{Qmax})\end{array}$ & $\begin{array}{c}\text { Actual } \\
\text { heat } \\
\text { transfer } \\
(\text { Qactual })\end{array}$ & $\begin{array}{c}\text { Outlet } \\
\text { temperature } \\
\text { of hot fluid } \\
\left(\mathrm{t}_{\mathrm{h} 2}\right)\end{array}$ & $\begin{array}{c}\text { Outlet } \\
\text { temperature } \\
\text { of Cold } \\
\text { fluid }\left(\mathrm{t}_{\mathrm{c} 2}\right)\end{array}$ \\
\hline 1. & 16 & 250 & 0.4644 & 2967162 & 1377950 & 163.44 & 132.16 \\
\hline 2. & 16 & 225 & 0.4644 & 2629984.5 & 1221364 & 148.28 & 120.55 \\
\hline 3. & 16 & 200 & 0.4644 & 2292807 & 1064779 & 133.11 & 108.94 \\
\hline 4. & 16 & 175 & 0.4644 & 1955629.5 & 908194 & 117.95 & 97.33 \\
\hline 5. & 16 & 150 & 0.4644 & 1618452 & 751609 & 102 & 85.72 \\
\hline 6. & 16 & 125 & 0.4644 & 1281274. & 595023 & 87.62 & 74.11 \\
\hline
\end{tabular}




\section{International Journal of Engineering Applied Sciences and Technology, 2019 \\ Vol. 4, Issue 7, ISSN No. 2455-2143, Pages 233-235 \\ Published Online November 2019 in IJEAST (http://www.ijeast.com)}

In above table we have calculated the Outlet temperature of both Exhaust fluid and Atmospheric air when $16 \mathrm{~kg} / \mathrm{s}$ of mass flow rate given at various Inlet temperature. Manipulating mass flow rate of Exhaust gas to get outlet temperature of Atmospheric air as $80^{\circ} \dot{\mathrm{m}}_{\mathrm{h}} * \mathrm{C}_{\mathrm{ph}} *\left(\mathrm{t}_{\mathrm{h} 1}-\mathrm{t}_{\mathrm{h} 2}\right)=\dot{\mathrm{m}}_{\mathrm{c}} * \mathrm{C}_{\mathrm{pc}} *\left(\mathrm{t}_{\mathrm{c} 2}-\mathrm{t}_{\mathrm{c} 1}\right)$
When,

$$
\begin{aligned}
& \mathrm{t}_{\mathrm{h} 1}=250^{\circ} \mathrm{C} \quad \mathrm{t}_{\mathrm{h} 2}=163.44^{\circ} \mathrm{C} \quad \mathrm{t}_{\mathrm{c} 2}=80^{\circ} \mathrm{C} \\
& \mathrm{t}_{\mathrm{c} 1}=30^{\circ} \mathrm{C} \\
& \dot{\mathrm{m}}_{\mathrm{c}}=13.42 \mathrm{~kg} / \mathrm{s} \\
& \therefore \dot{\mathrm{m}}_{\mathrm{h}} * 995^{*}(250- \\
& 163.44)=13.42^{*} 1005^{*}(80-30) \\
& \therefore \dot{\mathrm{m}}_{\mathrm{h}}=7.82 \mathrm{Kg} / \mathrm{g}
\end{aligned}
$$

Table no.3.3: Iteration for mass flow rate of Exhaust gas

\begin{tabular}{|c|c|c|c|}
\hline Sr. no. & Inlet temperature $\left(\mathrm{t}_{\mathrm{h} 1}\right)$ & $\begin{array}{c}\text { Outlet temperature } \\
\left(\mathrm{t}_{\mathrm{h} 2}\right)\end{array}$ & $\begin{array}{c}\text { Mass flow rate of exhaust } \\
\text { gas }\left(\dot{\mathrm{m}}_{\mathrm{h}}\right)\end{array}$ \\
\hline 1. & 250 & 163.44 & 7.82 \\
\hline 2. & 225 & 148.28 & 8.83 \\
\hline 3. & 200 & 133.11 & 10.13 \\
\hline 4. & 175 & 117.95 & 11.87 \\
\hline 5. & 150 & 102 & 14.11 \\
\hline 6. & 125 & 87.62 & 18.13 \\
\hline
\end{tabular}

As we got the various mass flow rate of exhaust gas depending on their available Inlet temperature so we can use a flow control valve before the inlet of the heat exchanger so that we can control the flow.

Cost associated with the steam being used as a hot fluid source in heat exchanger

\section{- Heat required for producing $1 \mathrm{~kg}$} steam

Assumption:

1) For making $1 \mathrm{~kg}$ of steam taking $1 \mathrm{~kg}$ of water

2) Let water be at room temperature

3) Taking no loss of heat in heating the water from $20^{\circ} \mathrm{C}$ to its boiling point and then converting water from $100^{\circ} \mathrm{C}$ to steam at $100^{\circ} \mathrm{C}$.

$\therefore$ Heat required to heat $1 \mathrm{gm}$ of water by $1^{\circ} \mathrm{C}$ is 1 calorie

$\therefore$ Heat required to heat $1000 \mathrm{gm}$ of water,

$\mathrm{Q}_{1}=1000 * 1 *(100-20)$

$\mathrm{Q}_{1}=80000$ Calorie

Now, each gram of water at $100^{\circ} \mathrm{C}$ requires 540 Calorie of heat to convert to steam at $100^{\circ} \mathrm{C}$

$\therefore$ Heat required to change $1000 \mathrm{gm}$ of water at $100^{\circ} \mathrm{C}$ to steam at $100^{\circ} \mathrm{C}$

$\mathrm{Q}_{2}=1000 * 540$

$\mathrm{Q}_{2}=540000$ Calorie

$\therefore$ Net Heat required to produce $1 \mathrm{~kg}$ of water to $1 \mathrm{~kg}$ of steam,

$\therefore \mathrm{Q}=80000+540000$

$\therefore \mathrm{Q}=620000$ Calorie

- Capacity of boiler section

Capacity: $10000 \mathrm{~kg} / \mathrm{hr}$

Per day coal consumption: $30000 \mathrm{~kg}$

Coal used: Bituminous Grade 7

Calorific value: 4500 to $5000 \mathrm{Kcal} / \mathrm{kg}$
Operating cycle: $24 \mathrm{hrs}$

Cost of coal: Average Rs $7 / \mathrm{kg}$

$\therefore$ In $1 \mathrm{~kg}$ of coal $8 \mathrm{~kg}$ of steam can be produced.

As about $22.6 \mathrm{~kg} / \mathrm{s}$ of steam were in use so we can see that per day $81360 \mathrm{~kg} / \mathrm{hr}$ of steam is used by hot air dryer

Hence associated cost for producing $542 \mathrm{~kg}$ of steam $10170 \mathrm{~kg}$ of coal required

$\therefore$ Total Rs 469 required per day

\section{CAD MODELLING}

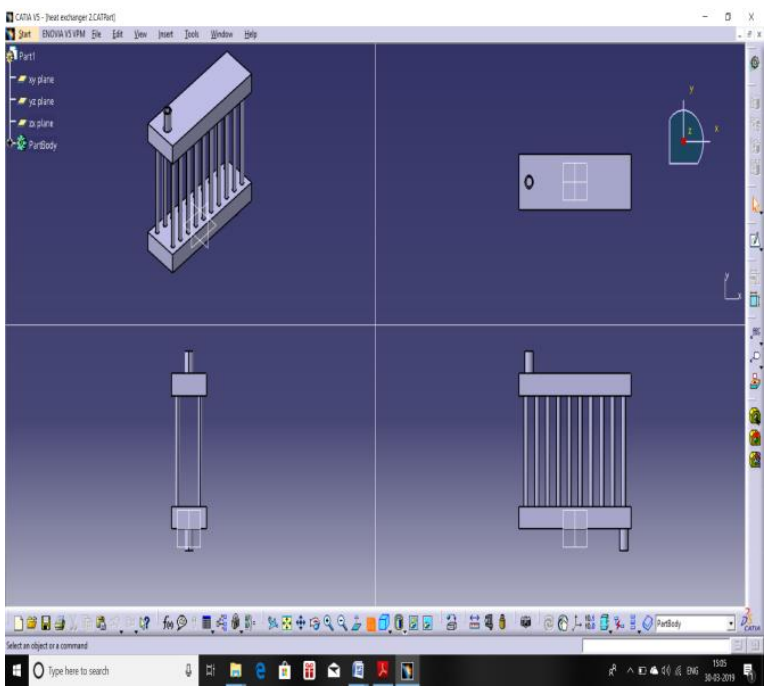

Fig3.1 CAD model of Heat exchanger

The 3D model depicts actual view of heat exchanger, the actual heat transfer area needs to be calculated accurately for which the cross flow heat exchanger has to be designed. Also number of tubes has to be decided on what amount of the heat is to be convected through convective heat transfer mod. 


\section{International Journal of Engineering Applied Sciences and Technology, 2019 Vol. 4, Issue 7, ISSN No. 2455-2143, Pages 233-235 \\ Published Online November 2019 in IJEAST (http://www.ijeast.com)}

\section{RESULT}

After calculating for various factors we found that,

- $\quad$ Finalized diameter of pipe as $381 \mathrm{~mm}$ made up of Mild Steel with a thermal conductivity of $50 \mathrm{w} / \mathrm{mk}$

- Heat loss through pipe can be vary according to thickness of insulation. (Refer Table 3.1)

- Using glass wool with thermal conductivity of $0.0372 \mathrm{w} / \mathrm{mk}$

- Total $674355 \mathrm{~W}$ of heat required by the air to raise its temperature to $80^{\circ} \mathrm{C}$

- Overall heat transfer for this heat exchanger is $6859.40 \mathrm{w} / \mathrm{m}^{2} \mathrm{k}$.

- Effectiveness for the heat exchanger came as 0.4644 which became the base for further calculations.

- When $16 \mathrm{~kg} / \mathrm{s}$ of exhaust flue gases supplied at $250^{\circ} \mathrm{C}$ the outlet temperature of Air reaches to $132^{\circ} \mathrm{C}$

- Table no.3.1 give the iterative value for the various available inlet temperature

- Table no3.2 gives the variation in mass flow rate of exhaust gas that to be made for getting $80^{\circ} \mathrm{C}$ of air in outlet.

\section{CONCLUSION}

From the result and discussion above we draw following conclusion on the Heat recovery from the exhaust flue gases.

- By this project work we have made efficient use of recovering heat before exhausting to atmosphere

- Replacement of steam will lead to saving of cost associated with steam generation

- It will reduce the effect of harmful gases on the atmosphere due to burning of coal

- This will save more water and cost associated with storage and maintenance form water requirement.

- It will reduce the handling cost of steam and labour requirement.

\section{FUTURE SCOPE}

- Material for exhaust gas delivery pipe can also be taken as Stainless Steel as its thermal conductivity is very low but cost is high.

- Better insulating method for pipe can be used.

- New heat exchanger suitable for exhaust gas can be used.

- Exhaust gas leaving the heat exchanger can be used for other works such as heating in rinsing tank.
- Hot air dryer can be made to work on electric heater.

\section{REFRENCE}

[1] Kemal comakli, Meryem Terhan., "Energy and economic analysis of heat recovery of boiler exhaust flue gases" World academy of science and technology International jouranal of energy and power engineering VOL:10,NO:4

[2] Nippon steel and sumkin engineering co. ltd, "exhaust heat recovery system of hot air stoves" Jase-w Japanees smart energy product and technology.

[3] EERE Energy, “ Install waste heat recovery system for fuel fired furnace" U.S. Department of energy, Washington DC 20585-0125

[4] Mashiro Osakabe, Sachiyo Horiki, "Latent heat recovery from oxygen combustion flue gases" Tokyo University of mercantilz marine, koutou-ku, Tokyo.

[5] L.Brand, W.Rose, "Measure guidelines high thermal natural gas furnace” U.S.Department of energy efficiency and renewable energy

[6] Hossam.E.Salekh,Ramadan MH,Elsanausi, "Performance and exhaust analysis of direct injection diesel engine running on dual fuel" International journal of engineering trends and technology, VOL:15,NO:2

[7] Albela.H.Pundkar, S.M.Lawankar, Dr.sameer deshmukh, "Performance and emission of LPG fuelled internal combustion engine" International journal of scientific and engineerinf reaserch VOL:3

[8] Feng LI, Lin Duanmu, Lin Fu, "Reaserch and application of flue gases wasre heat recovery in cogeneration based on absorption heat exchange" Science direct procedia engineering

[9] EERE Enegy, "Waste heat reduction and recovery for improving furnace efficiency,productivity, and mission performance" U.S.Department of energy, Washington DC 20585-0125.

[10] Chad Baker, Prem Vuppuluri, "Model of heat exchanger for waste heat recovery from diesel engine exhaust for thermoelectric power generation" Journals of Electronic material Vol 41 , no. 6 .

[11] Murtula Sani, "Heat source and radiation absorption effect on heat mass transfer flow with variable thermal conductivity" Continental J. Engineering Science DOI: 10-5281/ Zenodo 1975732.

[12] Chan-ki-jeon Joe-seong Lee Hoon chung, "Study of insulation characteristics of Glass wool and mineral wool coated with polysiloxane agent" Hindawi volume 2017 article I03938965. [13] Zhiwu Zhi-wu Liang, "Effects of flue gas composition on carbon steel (1020) corrosion in 
International Journal of Engineering Applied Sciences and Technology, 2019

Vol. 4, Issue 7, ISSN No. 2455-2143, Pages 233-235

Published Online November 2019 in IJEAST (http://www.ijeast.com)

MEA-based CO2 capture process" International Journal of Greenhouse Gas Control 19:340349 - November 2013

[14] Giurca, "Calculation of heat loss through the pipes of the interior central heating system" Technical University of Cluj-Napoca, Faculty Building Services Engineering, Building Services Engineering Department, B-dul.21
December 1989, no. 128-130, Cluj-Napoca, Romania.

[15] Kaiyang Li, Robin Hughes, and Jing-Li Luo, "Corrosion Mechanisms and Materials Selection for the Construction of Flue Gas Component in Advanced Heat and Power Systems" Ind. Eng. Chem. Res., 2017, 56 (48), pp 14141-14154 